Research Article

\title{
Comparison of BIM Adoption Models between Public and Private Sectors through Empirical Investigation
}

\author{
Solomon Belay $\mathbb{D D}^{1}{ }^{1}$ James Goedert, ${ }^{2}$ Asregedew Woldesenbet, ${ }^{3}$ and Saeed Rokooei $\mathbb{D}^{4}$ \\ ${ }^{1}$ Faculty of Civil and Water Resources Engineering, Bahir Dar University, Bahir Dar, Ethiopia \\ ${ }^{2}$ Durham School of Architectural Engineering and Construction, University of Nebraska-Lincoln, The Peter Kiewit Institute, \\ 1110 S 67th St., Omaha, NE 68182-0816, USA \\ ${ }^{3}$ Faculty of Civil and Water Resources Engineering, Bahir Dar University, Bahir Dar, Ethiopia \\ ${ }^{4}$ College of Architecture, Art and Design, Mississippi State University, 123-D Howell Building, Starkville, MS 39759, USA
}

Correspondence should be addressed to Solomon Belay; solomon.melaku@bdu.edu.et

Received 23 February 2021; Revised 8 April 2021; Accepted 17 April 2021; Published 29 April 2021

Academic Editor: Rafael J. Bergillos

Copyright $\odot 2021$ Solomon Belay et al. This is an open access article distributed under the Creative Commons Attribution License, which permits unrestricted use, distribution, and reproduction in any medium, provided the original work is properly cited.

\begin{abstract}
In recent years, the integration of new technology-aided processes and methods, such as BIM in complex infrastructure projects, is becoming popular in the construction sector. Despite the growing popularity of BIM in the built environment, there is still a dearth of studies that focus on the intersectorial comparison of BIM adoption drivers in construction projects. Thus, the study aims to examine the project-specific BIM adoption drivers across the public and private construction sectors. Initially, a hypothetical BIM adoption model was developed based on a systematic literature review and desk study. Then, a structured questionnaire survey was employed to collect data from experts working across the Ethiopian construction industry. The empirical data were analyzed using a structural equation modeling and validated through confirmatory factor analysis. The result reveals that Relative Advantage, Financial Competency, Top Management Support, and Customer Pressure are common BIM adoption drivers amongst the public and private construction sectors. Similarly, a few distinct drivers were identified within both sectors. These include Government Pressure and Social/Cultural Factors in public, whereas Competitor Pressure and Communication Behavior in the private construction sector. The paper provides key intersectorial BIM adoption drivers within different adoption stages to reinforce the effort across the public and private construction projects. In addition, practical implications and key recommendations were forwarded to enhance the current BIM uptake in the Ethiopian construction sector.
\end{abstract}

\section{Introduction}

The global construction industry is currently evolving due to the introduction of new technological advancements and innovations $[1,2]$. This rapid growth can be realized in the adoption of Building Information Modeling (BIM) in highvalue infrastructure projects across the construction sector [3]. BIM has been understood as an information technology (IT)-driven innovative process integrating certain features, disciplines, and life-cycle information of a facility within a single working platform [4]. In recent years, BIM has gained a global acceptance associated with its wide range of benefits in the construction business environment [5]. Developed countries in particular have been taking advantage of BIM in different stages of the construction process $[6,7]$.

As a technological innovative process, effective projectspecific BIM adoption schemes require a thoughtful and well-established strategy and implementation plan $[1,8]$. Adopting BIM in both public and private construction sectors entails collaborative integration of stakeholders in various stages of the project life cycle $[9,10]$. However, in the current construction business environment, it is imperative to denote that public and private projects have their own distinct features and characteristics. For instance, public infrastructure projects are deemed to be complex, require huge resources, and are typically financed by either 
government or international donors. Hence, implementing BIM in these projects is fairly distinct from the technological and innovation point of view and requires careful adoption strategies $[11,12]$. In contrast, the private sector, especially in low-income countries, is fragmented and collaboration among stakeholders is weak. This in turn greatly influences the overall project success and requires a project-oriented BIM adoption framework to enhance the project management performance in these projects $[13,14]$.

Prior studies emphasized BIM adoption frameworks from different categorical aspects. For instance, in organizational level, studies stressed the impact of financial capacity, practice, and readiness of major construction firms on the integration of BIM in organizational structures $[5,15]$, whereas in project and industry levels, they highlighted (1) barriers and benefits of BIM adoption and diffusion in the construction industry [16], (2) diffusion challenges associated with BIM implementation [17], and (3) critical strategies of BIM adoption across different markets [18].

However, there is still a dearth of studies in the current literature emphasizing on the intersectorial aspects of BIM adoption models in public and private construction sectors in emerging markets. To address this gap, this study aims to explore the key BIM adoption enablers and potential inhibitors across public and private projects in the context of the Ethiopian construction sector. Furthermore, the current study will examine and compare both models in relation to various technology adoption stages. The results of this study are believed to enhance the current BIM uptake in the Ethiopian construction sector by providing empirical evidences of BIM adoption drivers for public and private sectors. The results will also be helpful for construction business CEOs, stakeholders, and regulatory body to facilitate BIM adoption in construction projects.

\section{Literature Review}

This section covers background of the research and the strategy followed in the review of literature. The literature review presented in this paper is based on a thorough systematic literature review.

2.1. Research Background. Recently, the implementation of BIM in construction projects is growing in the construction business environment [19]. Previous studies highlighted that the extent and level of BIM uptake vary across construction market practices, as well as nature and complexity of projects $[8,20]$. These variables make it difficult to have a global comprehensive BIM adoption framework [21]. In addition, the majority of these studies are emphasized on the application of one of the commonly used BIM adoption frameworks.

For instance, Chen et al. [2] used the Technology-Organization-Environment (TOE) model to study the extent of BIM adoption trend in the Chinese construction industry. Similarly, Ahuja et al. [22] developed a TOE model to examine the factors influencing BIM adoption across India. A similar study by Lee et al. [9] reported the popularity of BIM within the South Korean construction industry using the technology acceptance model (TAM).

Moreover, Haron [11] implemented the Organizational Readiness Framework (ORF) to develop a comprehensive framework for consulting firms in Malaysia. The framework comprised of four distinct elements including distinct process in the structure of organizations, firm management, people (professionals), and technology. The other commonly used BIM adoption model is Innovation Diffusion theory (IDT). IDT describes the stages of technology/innovation adoption within an organization [23]. Rogers [23] describes the five stages of the innovation diffusion theory (IDT) as Awareness-Intention-Decision-Implementation-Diffusion.

So far, only a few studies have used a combination of the above models enhance BIM uptake in construction projects, although the simultaneous use of these adoption models helps to ease the sophisticated implementation of BIM from various perspectives [2]. A few recent cases include the following: Ahmed and Kassem [10] used TAM, IDT, TAM, and ORF models.

One of the key limitations in the present BIM literature is the fact that the majority of the studies conducted in developing countries did not consider the multidimensional nature of BIM in construction projects. This gap imposes the need for a unique BIM adoption model for the current Ethiopian construction market, considering the multidimensional nature of BIM and project-specific contextualities. More so, the other focus area that needs attention in the construction industry is concerned with intersectorial distinctions within construction projects. The division arises from the fact that BIM adoption success factors and key drivers may vary among the public and private construction sectors [12]. Thus, the present study aims to explore the comparative analysis of BIM adoption models between public and private construction sectors.

\section{Methodology}

The present study followed a three-stage scientific strategy to develop the hypothetical model and address the specific objectives. The first stage comprised of the systematic literature review to identify the potential BIM adoption drivers in developing countries. This method is particularly imperative to find a good quality and relevant publications in major databases [24]. In this case, a systematic literature review was conducted to identify key BIM adoption drivers and frameworks in developing countries. Then, the preselected pool of BIM adoption features was used to develop a hypothetical BIM adoption model and tested in the Ethiopian construction sector.

During the systematic literature review, a total of 12 research articles were shortlisted for questionnaire preparation. The research articles represent findings from different regions around the world. More so, the list of papers in Table 1 provides a clear overview of the different methodologies adopted to develop the research frameworks, and it also summarizes the top findings of those preselected 
TABle 1: Detail summary of shortlisted papers through a systematic literature review.

\begin{tabular}{|c|c|c|c|c|}
\hline No. & Author & Method & Drivers/factors & Country \\
\hline 1 & Babatunde et al. [20] & $\begin{array}{l}\text { Descriptive } \\
\text { statistics }\end{array}$ & $\begin{array}{c}\text { Cost and Time Saving, Improved Communication, BIM Awareness, and } \\
\text { Government Support }\end{array}$ & Nigeria \\
\hline 2 & $\begin{array}{l}\text { Ahmed and Suliman } \\
{[21]}\end{array}$ & SEM & $\begin{array}{c}\text { Competitive Strategies, Market Demand, Market Flexibility, Competitive } \\
\text { Advantages, Best Practices, BIM Benefits, and Team Expectations }\end{array}$ & Bahrain \\
\hline 3 & Mosse et al. [25] & $\begin{array}{l}\text { Descriptive } \\
\text { statistics }\end{array}$ & $\begin{array}{c}\text { Legal Issues, Knowledge and Awareness, Efficiency, Versatility, Leadership, } \\
\text { and Competitiveness }\end{array}$ & Kenya \\
\hline 4 & Chen et al. [2] & PLS-SEM & Relative Advantage, Top Management Support, and Organizational Readiness & China \\
\hline 5 & Ahuja et al. [22] & SEM & $\begin{array}{c}\text { Consistency, Availability of BIM Software, Favorable Attitude towards BIM, } \\
\text { Compatibility, Top Management Support, BIM Readiness, and Existing Green } \\
\text { Rating System Supporting BIM Adoption }\end{array}$ & India \\
\hline 6 & Kwofie et al. [26] & $\begin{array}{l}\text { Descriptive } \\
\text { statistics }\end{array}$ & $\begin{array}{l}\text { Accuracy of BIM-Adopted Communication, Timeliness in BIM } \\
\text { Communication, Overcoming Barriers, and Avoiding Distortions }\end{array}$ & $\begin{array}{l}\text { South } \\
\text { Africa }\end{array}$ \\
\hline 7 & Almuntaser et al. [27] & $\begin{array}{l}\text { Descriptive } \\
\text { statistics }\end{array}$ & $\begin{array}{c}\text { Faster Design Processes, Effective Reuse of Information, and Overall Client } \\
\text { Satisfaction }\end{array}$ & $\begin{array}{l}\text { Saudi } \\
\text { Arabia }\end{array}$ \\
\hline 8 & Ngowtanasawan [1] & SEM & Quality, Relative Advantage, Trialability, Ease of Use, and Compatibility & Thailand \\
\hline 9 & $\begin{array}{l}\text { Ozorhon and Karahan } \\
\qquad[12]\end{array}$ & ANOVA & $\begin{array}{l}\text { Availability of Qualified Staff, Effective Leadership, Availability of } \\
\text { Technology, Coordination among Parties, and Training of Employees }\end{array}$ & Turkey \\
\hline 10 & Enegbuma et al. [28] & SEM & $\begin{array}{c}\text { Business Process, Construction Business Reengineering, and Computer- } \\
\text { Integrated Construction }\end{array}$ & Malaysia \\
\hline 11 & Rogers et al. [29] & $\begin{array}{l}\text { Descriptive } \\
\text { statistics }\end{array}$ & $\begin{array}{c}\text { Construction firms were prepared to adopt BIM where market demands and } \\
\text { competitive advantage }\end{array}$ & Malaysia \\
\hline 12 & Masood et al. [30] & $\begin{array}{l}\text { Descriptive } \\
\text { statistics }\end{array}$ & $\begin{array}{c}\text { Effective Design Management, Quality of Construction, and Rework } \\
\text { Management }\end{array}$ & Pakistan \\
\hline
\end{tabular}

research articles along with the country the study was conducted. Consequently, those papers were targeted for questionnaire preparation, and as well as for model hypothesis development for this study. The basis of selecting these papers is briefly explained in Section 3.1. Table 1 presents the shortlisted research publications taken from the systematic literature review.

The second stage covers a pilot test to preassess the preselected drivers and check the questionnaire draft before the main data collection. Then, after correcting the feedbacks from the pilot test, the draft questionnaire was sent to a group of experienced experts for content analysis. Finally, the revised questionnaire draft was distributed to various professionals working across the Ethiopian construction industry.

3.1. Systematic Literature Review Steps. The systematic literature selection process was conducted in three stages. The first stage comprised of identifying papers in the biggest Internet databases such as Scopus and Google Scholar using the key word "BIM adoption in construction projects." This process resulted in 297 qualified publications.

In the second stage, the preretrieved papers were further refined using a content analysis technique. The criteria for the content analysis include the following: language (English), publication date (later than 2014), sector (public and private projects), method (structural equation modeling), and location (developing countries). The analysis resulted in 37 papers.

Finally, a detailed review was conducted to further identify papers that are relevant to the current research. The review carefully analyzed the research methodology, country, and scope of the preidentified publications. During this process, a total of 10 journal articles and 2 conference proceedings were refined focusing on structural equation modeling and developing countries. The systematic literature review process is summarized in Figure 1.

3.2. Pilot Test. The present study employed a pilot test for the purpose of contextualizing the preselected BIM adoption drivers against the Ethiopian construction sector. Around 10 experienced participants were asked to carefully review, change, and amend the preselected drivers for the purpose of contextualizing the study to the Ethiopian construction setting.

During the pilot study, the experts pressed "Social/ Cultural Factors" to be included in the hypothetical model and discard a few factors that are not viable in the current construction practices. These factors were: "Model Interoperability," "Automation and AI," "Adoption Incentives," "Cloud Data Exchange," "Partner Influence," "Observability," and "Real-Time Data Usage."

3.3. Development of the Model Hypothesis. The proposed BIM adoption model developed for this study is based on the Technology-Organization-Environment (TOE) framework in combination with Innovation Diffusion theory and Organizational Readiness Framework. The exogenous constructs of the model consist of three BIM adoption aspects (Technology, Organization, and Environment), eleven drivers, and thirty-two factors. The endogenous constructs including the hypothesis are then formulated using the three pre-BIM adoption stages: Awareness-Intention-Decision. The final model of the study is illustrated in Figure 2. 


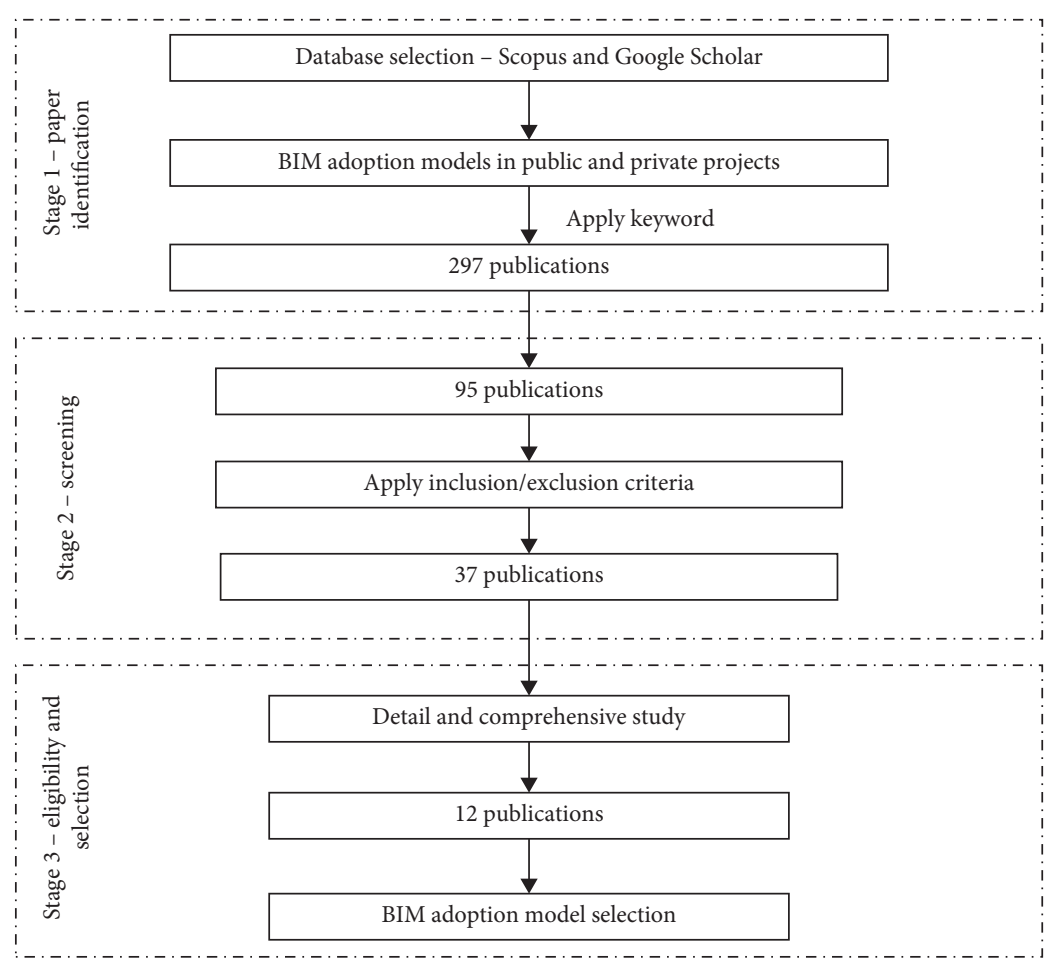

FIgURE 1: Systematic literature review flowchart.

3.3.1. Technology Aspect. Technology is one of the three major aspects of the TOE theory which focuses on the external and internal technological advancements in organizations, and the disadvantages associated with adapting new technology in different organizational structures $[14,22]$. Prior studies revealed that drivers such as Relative Advantage, Compatibility, and Complexity of the BIM technology to be adopted are grouped under the technological aspects of the BIM adoption model [10, 28]. The hypothesis formulated about the effect of technology in different adoption stages is shown in Table 2.

3.3.2. Organization Aspect. Organizational aspects emphasize the organizational BIM adoption goals and characteristics with respect to work flow and resources available for an innovation [1]. The literature reveals that Top Management Support, Organizational Readiness, Financial Competency, Communication Behavior, and Cultural Factors should be taken into account for the successful adoption of BIM in construction and consulting firms [2, 10]. Table 3 summarizes the hypothesis related to the effect of organizational aspects in BIM adoption stages.

3.3.3. Environment Aspect. Environmental aspects refer to the pressures from external environmental influence on the firm's ability to adopt an innovation [10]. These pressures include Customer Pressure, Government Pressure, and Competitive Pressure [2, 22]. Prior studies reported that governmental entities can exert external pressure using policies and legal guidelines to encourage firms to adopt new innovations for better competitiveness on the market [21].
Similarly, pressure from competitors, as well as customers, affects a firm's capabilities and encourages a firm to adopt new technologies and innovations [2]. The hypothesis about the effect of environmental aspects in public and private sectors across all BIM adoption stages is illustrated in Table 4 .

3.4. Questionnaire Development. Initially, a preliminary draft questionnaire was prepared after the pilot study. The structured questionnaire draft comprised of 4 sections. The first section aims to assess the demographic information of respondents whereas the second section of the questionnaire consists of 5 items that are related to respondent's firm profile. The third section is the main part of the questionnaire which contains all the question items of the hypothetical model. The final (forth) section comprised of brief information (definition) of the drivers and indicators given in Section 3.

Then, the questionnaire draft was sent to 2 experienced professionals working in the academia and the industry with more than 15 years of professional experience. The purpose of this step is to do a content analysis and to check the language usage of the first draft. Finally, after correcting the feedback from experts, the final questionnaire was printed for the main data collection.

3.5. Data Collection. During the data collection stage, two main types of collection methods were deployed: face to face distribution and popular online platforms such as e-mail and telegram. A total of 298 questionnaires were distributed in both public and private construction projects throughout 


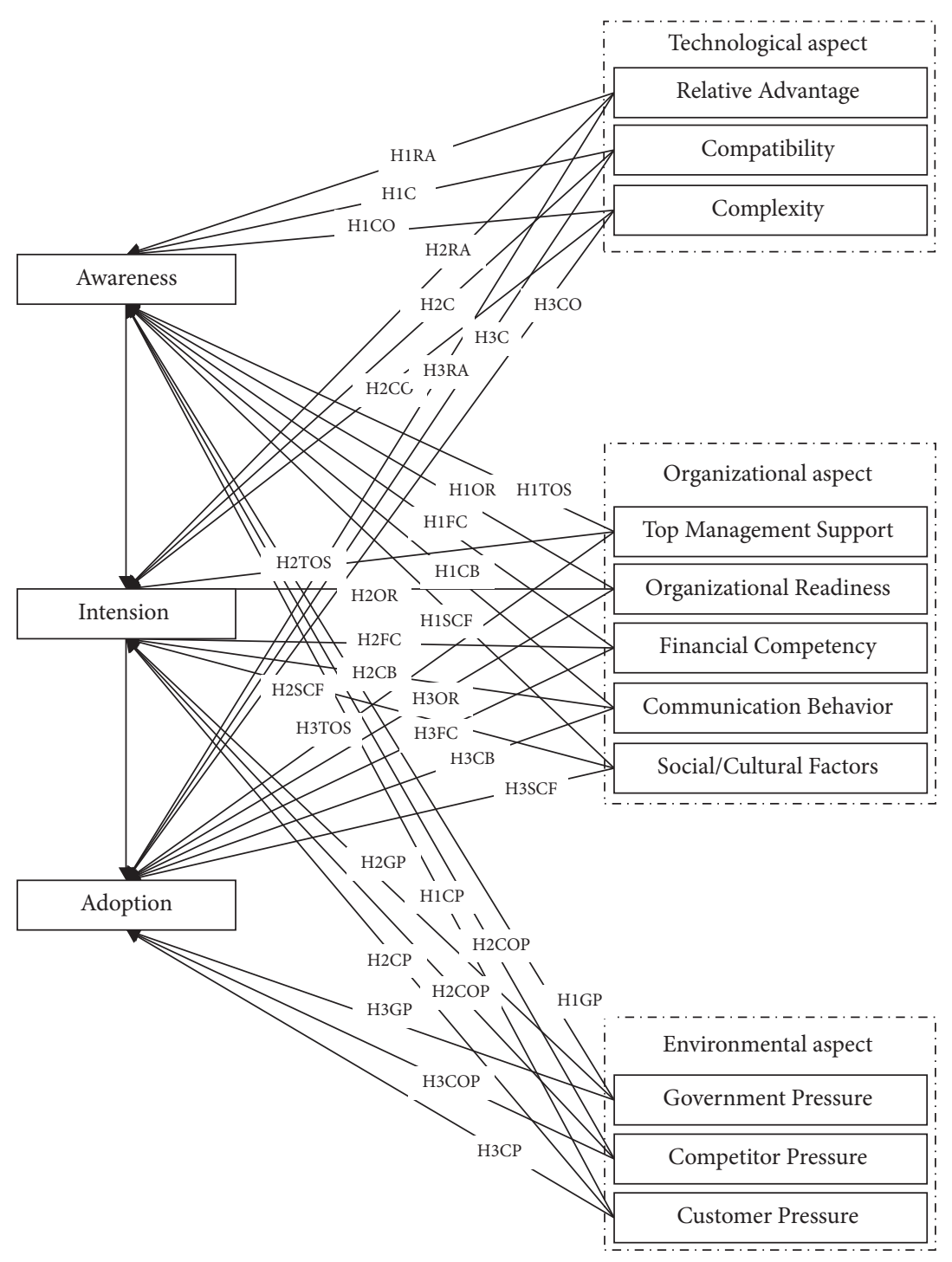

Figure 2: Hypothetical structural equation model.

TABLE 2: Hypothesis about the effect of technological aspect in public and private sectors across adoption stages.

\begin{tabular}{|c|c|c|}
\hline Drivers & Coding & Null hypothesis (Ho) \\
\hline Relative Advantage & $\begin{array}{l}\text { H1RA } \\
\text { H2RA } \\
\text { H3RA }\end{array}$ & $\begin{array}{l}\text { Relative Advantage positively affects BIM awareness in public and private construction projects } \\
\text { Relative Advantage affects an intention to adopt BIM in public and private construction projects } \\
\text { Relative Advantage affects the decision to adopt BIM in public and private construction projects }\end{array}$ \\
\hline Compatibility & $\begin{array}{l}\mathrm{H} 1 \mathrm{C} \\
\mathrm{H} 2 \mathrm{C} \\
\mathrm{H} 3 \mathrm{C}\end{array}$ & $\begin{array}{l}\text { Compatibility positively affects BIM awareness in public and private construction projects } \\
\text { Compatibility positively affects an intention to adopt BIM in public and private construction projects } \\
\text { Compatibility positively affects the decision to adopt BIM in public and private construction projects }\end{array}$ \\
\hline Complexity & $\begin{array}{l}\mathrm{H} 1 \mathrm{CO} \\
\mathrm{H} 2 \mathrm{CO} \\
\mathrm{H} 3 \mathrm{CO}\end{array}$ & $\begin{array}{l}\text { Complexity affects BIM awareness in public and private construction projects } \\
\text { Complexity affects an intention to adopt BIM in public and private construction projects } \\
\text { Complexity affects the decision to adopt BIM in public and private construction projects }\end{array}$ \\
\hline
\end{tabular}

the major metropolitan cities in the country. After a few weeks, around 201 questionnaires were returned, which shows a $68 \%$ response rate. From this, 108 valid responses were collected from the public sector, and 93 responses from the private sector were used for further analysis.
3.6. Demography of Participants. The demographic profile of respondents consists of position in a company, year of experience, level of education, and the type of organization within the public and private construction projects in the Ethiopian construction sector (Table 5). 
TABLE 3: Hypothesis about the effect of organizational aspects in public and private sectors across all adoption stages.

\begin{tabular}{|c|c|c|}
\hline Drivers & Coding & Null hypothesis (Ho) \\
\hline \multirow{3}{*}{ Top Management Support } & H1TOS & Top Management Support affects BIM awareness in public and private construction projects \\
\hline & H2TOS & $\begin{array}{c}\text { Top Management Support affects an intention to adopt BIM in public and private construction } \\
\text { projects }\end{array}$ \\
\hline & H3TOS & $\begin{array}{c}\text { Top Management Support affects the decision to adopt BIM in public and private construction } \\
\text { projects }\end{array}$ \\
\hline \multirow{3}{*}{ Organizational Readiness } & H1OR & Organizational Readiness affects BIM awareness in public and private construction projects \\
\hline & $\mathrm{H} 2 \mathrm{OR}$ & $\begin{array}{c}\text { Organizational Readiness affects an intention to adopt BIM in public and private construction } \\
\text { projects }\end{array}$ \\
\hline & $\mathrm{H} 3 \mathrm{OR}$ & $\begin{array}{c}\text { Organizational Readiness affects the decision to adopt BIM in public and private construction } \\
\text { projects }\end{array}$ \\
\hline \multirow{3}{*}{ Financial Competency } & H1FC & Financial Competency affects BIM awareness in public and private construction projects \\
\hline & $\mathrm{H} 2 \mathrm{FC}$ & Financial Competency affects an intention to adopt BIM in public and private construction projects \\
\hline & $\mathrm{H} 3 \mathrm{FC}$ & Financial Competency affects the decision to adopt BIM in public and private construction projects \\
\hline \multirow{3}{*}{ Communication Behavior } & $\mathrm{H} 1 \mathrm{CB}$ & Communication Behavior affects BIM awareness in public and private construction projects \\
\hline & $\mathrm{H} 2 \mathrm{CB}$ & $\begin{array}{c}\text { Communication Behavior affects an intention to adopt BIM in public and private construction } \\
\text { projects }\end{array}$ \\
\hline & $\mathrm{H} 3 \mathrm{CB}$ & $\begin{array}{c}\text { Communication Behavior affects the decision to adopt BIM in public and private construction } \\
\text { projects }\end{array}$ \\
\hline \multirow{3}{*}{ Social/Cultural Factors } & H1SCF & Social/Cultural Factors positively affect BIM awareness in public and private construction projects \\
\hline & $\mathrm{H} 2 \mathrm{SCF}$ & Social/Cultural Factors affect an intention to adopt BIM in public and private construction projects \\
\hline & H3SCF & Social/Cultural Factors affect the decision to adopt BIM in public and private construction projects \\
\hline
\end{tabular}

TABLE 4: Hypothesis about the effect of environmental aspects in public and private sectors across adoption stages.

\begin{tabular}{lcc}
\hline Drivers & Coding & Null hypothesis (Ho) \\
\hline \multirow{3}{*}{ Government Pressure } & H1GP & Public and private projects which are under Government Pressure might have BIM awareness \\
& H2GP & Public and private projects which are under Government Pressure have an intention to adopt BIM \\
& H3GP & Public and private projects which are under Government Pressure might decide to adopt BIM \\
\hline \multirow{3}{*}{ Competitor Pressure } & H1COP & Public and private projects which are under Competitors Pressure might have BIM awareness \\
& H2COP & Public and private projects which are under Competitor Pressure have an intention to adopt BIM \\
& H3COP & Public and private projects which are under Competitor Pressure might decide to adopt BIM \\
\hline \multirow{3}{*}{ Customer Pressure } & H1CP & Public and private projects which are under Customer Pressure might have BIM awareness \\
& H2CP & Public and private projects which are under Customer Pressure have an intention to adopt BIM \\
& H3CP & Public and private projects which are under Customer Pressure might decide to adopt BIM \\
\hline
\end{tabular}

3.7. Data Analysis. This study adopted structural equation modeling (SEM) to analyze and validate the BIM adoption empirical data collected from professionals working in both public and private construction projects across the Ethiopian construction sector.

3.7.1. Reasons for Using Structural Equation Modeling (SEM). SEM is a sophisticated and multivariate statistical approach, which is popular in different academic fields, ranging from social to natural science fields [31]. Recently, SEM is becoming prevalent in the field of construction engineering and management. The popularity of SEM in BIM adoption studies is linked to the fact that SEM allows for the analysis of direct and indirect impacts of latent constructs between exogenous and endogenous variables [32]. In addition, SEM is an important statistical analysis tool which helps to examine the correlation (relationship) between observed and measured factors using a path diagram $[1,33]$.

\section{Analysis and Findings}

This section describes the empirical results of the public and private construction sectors.

4.1. Model Fit. The model fit (goodness-of-fit) for both public and private construction projects was computed against common measure indexes such as normed chisquare (CMIN/DF), root mean square residual (RMR), comparative fit index (CFI), and root mean square error of approximation (RMSEA). The cutoff fitness ranging values are summarized in Table 6.

The empirical data collected through a structured questionnaire survey were analyzed using statistical software IBM $^{\circledR}$ SPSS ${ }^{\circledR}$ AMOS 23 . The model fit index result indicates that, for public construction projects, the model was iterated four times before achieving model fit values of CMIN/ $\mathrm{DF}=1.894 ; \mathrm{RMR}=0.055 ; \mathrm{CFI}=0.899 ;$ and $\mathrm{RMSEA}=0.91$. 
TABLE 5: Demographic summary of participants.

\begin{tabular}{|c|c|c|c|c|}
\hline \multirow[b]{2}{*}{ Demography } & \multicolumn{2}{|c|}{ Number } & \multicolumn{2}{|c|}{ Percentage } \\
\hline & $\begin{array}{l}\text { Public } \\
\text { (P1) }\end{array}$ & $\begin{array}{l}\text { Private } \\
\text { (P2) }\end{array}$ & $\begin{array}{l}\text { Public } \\
\text { (P1) }\end{array}$ & $\begin{array}{l}\text { Private } \\
\text { (P2) }\end{array}$ \\
\hline $\begin{array}{l}\text { No. of } \\
\text { respondents }\end{array}$ & 108 & 93 & - & - \\
\hline \multicolumn{5}{|l|}{ Profession } \\
\hline Civil & 51 & 31 & 47.2 & 33.33 \\
\hline Architecture & 34 & 42 & 31.4 & 45.16 \\
\hline Construction & 23 & 19 & 21.4 & 21.51 \\
\hline \multicolumn{5}{|l|}{$\begin{array}{l}\text { Level of } \\
\text { education }\end{array}$} \\
\hline PhD & 1 & - & 0.09 & - \\
\hline $\mathrm{MSc}$ & 87 & 61 & 80.5 & 65.6 \\
\hline $\mathrm{BSc}$ & 20 & 32 & 18.5 & 34.4 \\
\hline \multicolumn{5}{|l|}{$\begin{array}{l}\text { Experience } \\
\text { (years) }\end{array}$} \\
\hline $0-5$ & 4 & 11 & 3.7 & 11.82 \\
\hline $6-10$ & 25 & 37 & 23.15 & 39.78 \\
\hline $11-15$ & 58 & 32 & 53.7 & 34.40 \\
\hline$>15$ & 21 & 13 & 19.45 & 14 \\
\hline \multicolumn{5}{|l|}{ Organization } \\
\hline Client & 14 & 3 & 13 & 3.23 \\
\hline Consultant & 31 & 71 & 28.7 & 76.34 \\
\hline Contractor & 52 & 15 & 48.15 & 16.13 \\
\hline Academia & 11 & 4 & 10.15 & 4.3 \\
\hline
\end{tabular}

TABLE 6: Summary of goodness-of-fit cutoff values.

\begin{tabular}{lc}
\hline Measure & $\begin{array}{c}\text { Acceptable } \\
\text { range }\end{array}$ \\
\hline Normed chi-square (CMIN/DF) & $1-3$ \\
Root mean square residual (RMR) & $<0.1$ \\
Comparative fit index (CFI) & $>0.8$ \\
Root mean square error of approximation & $<0.1$ \\
(RMSEA) & \\
\hline
\end{tabular}

In which case, all the model fit measures satisfy all the threshold acceptable ranges given in Table 6. It can be concluded that the P1 model achieve a very good fit.

Considering that, for private construction projects, the values were iterated twice to achieve model fit. Finally, the retained fit indices are $\mathrm{CMIN} / \mathrm{DF}=2.794 ; \mathrm{RMR}=0.073$; $\mathrm{CFI}=0.803$; and RMSEA $=0.1$. All the values are within the acceptable ranges. Hence, the model is considered to be a good fit.

4.2. Measurement Model. A confirmatory factor analysis, also known as CFA, was adopted to explore the reliability and validity of model items. The measurement model consists of three exogenous BIM adoption drivers: Technology, Organizational and Environmental and 11 aspects under each driver. The measurement model CFA values for both public and private construction projects are summarized in Table 7.

4.3. Reliability of the CFA Models. The reliability of both CFA models (public and private sectors) was evaluated using measures such as composite reliability, average variance extracted, internal consistency (Cronbach's alpha), and squared multiple correlation. The acceptable limit of reliability measures is summarized in Table 8 .

Based on the analysis, all the endogenous constructs have $\alpha$ values ranging from $0.79-0.95$ for public and $0.87-0.97$ for private construction projects (Table 7). In which case, all the $\alpha$ values exceed the minimum acceptable value of 0.7 , indicating sufficient reliability of empirical data. For the case of Composite Reliability (CR), as it is shown in Table 7, all the constructs for both public and private construction projects have exceeded the minimum acceptable CR value of 0.7 which is indicating a good reliability result.

Similarly, the AVE values of all constructs in the public construction projects range between 0.66 and 0.93 and constructs in the private construction projects range between 0.69 and 0.93 . In both cases, all the AVE values exceed the minimum threshold of 0.5 . Hence, both models satisfy the AVE reliability measure. In addition, the minimum acceptable SMC value for reliability measure is 0.3 (Table 8). The model results for both public and private construction projects have all exceeded 0.3 which confirms a very good reliability as well.

4.4. Validity Measurement of CFA Models. For public construction projects, convergent validity and discriminant validity tests were conducted to examine the validity measurement of the BIM adoption CFA model. Convergent validity evaluates the relationship between observed variables and aspects (latent variables) in terms of factor loadings [2]. If the factor loadings exceed 0.5 , then it is considered to be valid [32]. As it is shown in Table 4, the minimum factor loading for the public (P1) and private (P2) models is 0.75 which is greater than the lower threshold value of 0.5 . Hence, both models satisfied the convergent validity measure.

Similarly, discriminant validity explores the inconsistency between the path analysis and statistical analysis [10]. Discriminant validity is evaluated by comparing the AVE of each construct with the variance of the same construct with other constructs [2]. The higher the AVE value against its correlation with other determinants, the model is most likely to be valid. As it is summarized in Table 9, all the BIM adoption drivers fulfil the above requirement of discriminant validity.

Moreover, since the diagonal square root AVE values for each construct are higher than the correlations with other constructs, the P2 model also satisfies the requirement of discriminant validity. Hence, the model is considered to be valid as well (Table 10).

4.5. Structural Model. The hypothesis formulated in the study was analyzed in the structural model. The structural model is constructed based on 11 drivers as exogenous variables and three endogenous BIM adoption phases, namely, Awareness, Intension, and Decision. The structural model for the public (P1) construction sector satisfied all the model fit indices with criteria values of $\mathrm{CMIN} / \mathrm{DF}=1.89$; $\mathrm{RMR}=0.5 ; \mathrm{CFI}=0.887$; and RMSEA $=0.091$. Similarly, the 
TABLE 7: Summary of the measurement model result for public and private projects.

\begin{tabular}{|c|c|c|c|c|c|c|c|c|c|c|c|}
\hline \multirow[t]{2}{*}{ Drivers } & \multirow[t]{2}{*}{ Items } & \multicolumn{2}{|c|}{ Factor loading } & \multicolumn{2}{|c|}{ SMC (R2) } & \multicolumn{2}{|c|}{$\mathrm{CR}$} & \multicolumn{2}{|c|}{ AVE } & \multicolumn{2}{|c|}{$\begin{array}{c}\text { Cronbach's } \\
\text { alpha }\end{array}$} \\
\hline & & Public (P1) & Private (P2) & P1 & $\mathrm{P} 2$ & $\mathrm{P} 1$ & $\mathrm{P} 2$ & $\mathrm{P} 1$ & $\mathrm{P} 2$ & $\mathrm{P} 1$ & $\mathrm{P} 2$ \\
\hline \multirow{3}{*}{ Relative Advantage (RA) } & Q1_RA1 & 0.77 & 0.86 & 0.60 & 0.67 & 0.87 & 0.88 & 0.69 & 0.71 & 0.86 & 0.84 \\
\hline & Q2_RA2 & 0.92 & 0.75 & 0.84 & 0.75 & & & & & & \\
\hline & Q3_RA3 & 0.79 & 0.78 & 0.63 & 0.69 & & & & & & \\
\hline \multirow{2}{*}{ Compatibility (C) } & Q4 4 C1 & 0.91 & 0.93 & 0.83 & 0.87 & 0.93 & 0.92 & 0.87 & 0.84 & 0.93 & 0.91 \\
\hline & Q5_C2 & 0.95 & 0.91 & 0.89 & 0.82 & & & & & & \\
\hline \multirow{3}{*}{ Complexity (CO) } & Q6_CO1 & 0.79 & 0.86 & 0.62 & 0.73 & 0.87 & 0.88 & 0.70 & 0.71 & 0.87 & 0.87 \\
\hline & Q7_CO2 & 0.91 & 0.91 & 0.82 & 0.84 & & & & & & \\
\hline & Q8_CO3 & 0.80 & 0.75 & 0.63 & 0.57 & & & & & & \\
\hline \multirow{2}{*}{ Top Management Support (TOS) } & Q9_TOS1 & 0.85 & 0.91 & 0.73 & 0.81 & 0.88 & 0.89 & 0.93 & 0.80 & 0.87 & 0.92 \\
\hline & Q10_TOS2 & 0.9 & 0.94 & 0.81 & 0.79 & & & & & & \\
\hline \multirow{3}{*}{ Organizational Readiness (OR) } & Q12_OR1 & 0.84 & 0.91 & 0.71 & 0.63 & 0.87 & 0.87 & 0.79 & 0.69 & 0.88 & 0.88 \\
\hline & Q13_OR2 & 0.93 & 0.85 & 0.86 & 0.77 & & & & & & \\
\hline & Q14_OR3 & & 0.77 & & 0.66 & & & & & & \\
\hline \multirow{2}{*}{ Financial Competency (FC) } & Q16_FC1 & 0.75 & 0.91 & 0.56 & 0.80 & 0.84 & 0.89 & 0.72 & 0.81 & 0.83 & 0.89 \\
\hline & Q17_FC2 & 0.94 & 0.9 & 0.89 & 0.82 & & & & & & \\
\hline \multirow{2}{*}{ Communication Behavior (CB) } & Q18_CB1 & 0.93 & 0.98 & 0.86 & 0.74 & 0.89 & 0.91 & 0.81 & 0.83 & 0.89 & 0.96 \\
\hline & Q19_CB2 & 0.87 & 0.94 & 0.76 & 0.92 & & & & & & \\
\hline \multirow{3}{*}{ Social/Cultural Factors (SCF) } & Q20_SCF1 & 0.91 & 0.94 & 0.83 & 0.39 & 0.90 & 0.88 & 0.74 & 0.74 & 0.88 & 0.93 \\
\hline & Q21_SCF2 & 0.78 & 0.88 & 0.60 & 0.69 & & & & & & \\
\hline & Q22_SCF3 & 0.89 & 0.9 & 0.79 & 0.82 & & & & & & \\
\hline \multirow{2}{*}{ Government Pressure (GP) } & Q23_GP1 & 0.92 & 0.97 & 0.84 & 0.91 & 0.95 & 0.97 & 0.9 & 0.93 & 0.95 & 0.86 \\
\hline & Q24_GP2 & 0.98 & 0.96 & 0.96 & 0.96 & & & & & & \\
\hline \multirow{3}{*}{ Competitor Pressure (MP) } & Q25_COP1 & 0.88 & 0.91 & 0.78 & 0.81 & 0.88 & 0.92 & 0.71 & 0.81 & 0.88 & 0.83 \\
\hline & Q26_COP2 & 0.89 & 0.88 & 0.80 & 0.79 & & & & & & \\
\hline & Q27_COP3 & 0.76 & 0.9 & 0.57 & 0.82 & & & & & & \\
\hline \multirow{2}{*}{ Customer Pressure (CP) } & Q28_CP1 & 0.85 & 0.89 & 0.72 & 0.70 & 0.79 & 0.89 & 0.66 & 0.79 & 0.79 & 0.78 \\
\hline & Q29_CP2 & 0.77 & 0.9 & 0.59 & 0.83 & & & & & & \\
\hline
\end{tabular}

$\mathrm{SMC}=$ squared multiple correlation; $\mathrm{CR}=$ composite reliability; $\mathrm{AVE}=$ average variance extracted.

TABLE 8: Acceptable values for evaluation of model reliability.

\begin{tabular}{lcc}
\hline Reliability measures & Symbol & Acceptable range for SEM model reliability \\
\hline Internal consistency (Cronbach's alpha) & $\alpha$ & $>0.7$ \\
Average variance extracted & AVE & $>0.5$ \\
Composite reliability & CR & $>0.7$ \\
Squared multiple correlation & SMC $\left(R^{2}\right)$ & $>0.5$ \\
\hline
\end{tabular}

TABLE 9: Interconstruct correlation (discriminant validity) for public construction projects.

\begin{tabular}{|c|c|c|c|c|c|c|c|c|c|c|c|}
\hline & RA & $\mathrm{C}$ & $\mathrm{CO}$ & TOS & OR & $\mathrm{FC}$ & $\mathrm{CB}$ & SCF & GP & $\mathrm{COP}$ & $\mathrm{CP}$ \\
\hline RA & 0.831 & & & & & & & & & & \\
\hline $\mathrm{C}$ & 0.539 & 0.930 & & & & & & & & & \\
\hline $\mathrm{CO}$ & 0.385 & 0.546 & 0.835 & & & & & & & & \\
\hline TOS & 0.408 & 0.468 & 0.321 & 0.875 & & & & & & & \\
\hline OR & 0.360 & 0.178 & 0.116 & 0.173 & 0.886 & & & & & & \\
\hline $\mathrm{FC}$ & 0.339 & 0.417 & 0.249 & 0.378 & 0.089 & 0.850 & & & & & \\
\hline $\mathrm{CB}$ & 0.745 & 0.586 & 0.536 & 0.435 & 0.257 & 0.360 & 0.901 & & & & \\
\hline SCF & 0.598 & 0.675 & 0.432 & 0.516 & 0.329 & 0.375 & 0.635 & 0.862 & & & \\
\hline GP & 0.694 & 0.835 & 0.571 & 0.440 & 0.349 & 0.358 & 0.806 & 0.688 & 0.950 & & \\
\hline COP & 0.570 & 0.396 & 0.270 & 0.686 & 0.206 & 0.370 & 0.453 & 0.507 & 0.472 & 0.845 & \\
\hline $\mathrm{CP}$ & 0.043 & -0.05 & 0.008 & 0.194 & 0.287 & -0.05 & 0.165 & 0.077 & 0.110 & 0.381 & 0.811 \\
\hline
\end{tabular}

The diagonal values are the square root values of AVE values of each driver. 
TABLE 10: Interconstruct correlation (discriminant validity) for private construction projects.

\begin{tabular}{lcccccccccc}
\hline & RA & C & CO & TOS & OR & FC & CB & SCF & GP & COP \\
\hline RA & $\mathbf{0 . 8 4 0}$ & & & & & & & & & \\
C & 0.333 & $\mathbf{0 . 9 1 9}$ & & & & & & & \\
CO & 0.214 & 0.051 & $\mathbf{0 . 8 4 4}$ & & & & & & \\
TOS & 0.445 & 0.250 & 0.09 & $\mathbf{0 . 8 9 2}$ & & & & & \\
OR & 0.078 & 0.335 & 0.226 & 0.523 & $\mathbf{0 . 8 3 0}$ & & & & \\
FC & 0.339 & 0.435 & 0.044 & 0.577 & 0.398 & $\mathbf{0 . 9 0 0}$ & & & & \\
CB & 0.427 & 0.591 & 0.192 & 0.437 & 0.400 & 0.590 & $\mathbf{0 . 9 1 2}$ & & \\
SCF & -0.14 & -0.12 & -0.21 & -0.05 & -0.09 & 0.035 & -0.1 & $\mathbf{0 . 8 6 2}$ & \\
GP & 0.589 & 0.570 & 0.184 & 0.569 & 0.571 & 0.727 & 0.772 & -0.43 & $\mathbf{0 . 9 6 6}$ & \\
COP & -0.14 & 0.005 & -0.2 & -0.08 & -0.24 & 0.083 & 0.096 & 0.754 & 0.098 & $\mathbf{0 . 8 9 6}$ \\
CP & 0.349 & -0.03 & 0.023 & 0.156 & 0.383 & 0.09 & -0.1 & -0.5 & 0.123 & -0.29 \\
\hline
\end{tabular}

private $(\mathrm{P} 2)$ model fit values $\mathrm{CMIN} / \mathrm{DF}=2.625 ; \mathrm{RMR}=0.68$; $\mathrm{CFI}=0.799$; and RMSEA $=0.103$ are within the acceptable limits. The regression analysis estimates for both structural models are summarized in Table 11.

In the case of the public construction sector, drivers such as Relative Advantage, Financial Competency, Government Pressure, Customer Pressure, and Social/Cultural Factors are significant with positive estimates and respective $p$ values of less than the threshold 0.05 in all BIM adoption phases. This reveals the initial hypothesis that H1RA, H2RA, H3RA, H1FC, H2FC, H3FC, H1GP, H2GP, H1CP, H2CP, H3CP and H1SCF, H2SCF, and H3SCF are significant for BIM adoption whereas the hypothesis of Top Management Support $(\mathrm{H} 1 \mathrm{TOS}=0.778)$ is significant only in the Awareness stage with a $p$ value of 0.49 .

As for private projects, all the hypotheses for adoption drivers such as Relative Advantage (H1RA, H2RA, and H3RA), Competitor Pressure (H1COP, H2COP, and H3COP), and Financial Competency (H1FC, H2FC, and $\mathrm{H} 3 \mathrm{FC}$ ) have $p$ values less than 0.05 in all BIM adoption stages. Thus, the null hypothesis is rejected, and those factors are considered to be significant for BIM adoption in private construction projects. Similarly, Customer Pressure (H2CP and $\mathrm{H} 3 \mathrm{CP}$ ) is significant in Intention and Decision stages with $p$ values of 0.33 and 0.046 , respectively whereas the hypothesis, Communication Behavior (H1CB), is significant in the Awareness stage with a $p$ value of 0.003 .

In general, the above hypothesis testing results reveal that Relative Advantage, Financial Competency, and Customer Pressure are common BIM adoption drivers in both sectors whereas Government Pressure and Top Management Support are distinct for public sector and Competitor Pressure is distinct to private sector at all BIM adoption stages.

\section{Discussion and Implication}

The present study demonstrated the relationship between public and private construction projects on the BIM adoption drivers across the Ethiopian construction sector. The paper employed SEM-based models using the combination of technology adoption theories. The hypothesis testing was conducted through the IDT's technology adoption phases: pre-BIM adoption stage and post-BIM adoption stage [10].

The pre-adoption stage emphases on the adopter's prior knowledge, interest, initiative, and choice towards the adoption of BIM in construction projects [10]. This stage is comprised of three distinct phases such as Awareness-Intention-Decision. Awareness is the first phase of the preBIM adoption stage which focuses on the basic understanding of the existence of Building Information Modeling [7]. Intention phase focuses on the level of interest of employees, top management, and CEO of a firm to adopt an innovation in the organizational structure. Correspondingly, the Decision phase is the third phase of the pre-BIM adoption stage where the construction organization decides whether to adopt or reject BIM.

Similarly, the post-adoption stage consists of the Implementation and Diffusion phases. These phases emanate after a firm has passed the point of adoption and decided to adopt BIM in construction projects [34]. For the current study, the pre-BIM adoption stage is employed for hypothesis testing since the aim of this paper is to investigate the enablers and inhibitors of BIM adoption in projects, and also the majority of construction firms in Ethiopia are currently in early stages. The IDT BIM adoption stages are illustrated in Figure 3.

5.1. Intersectorial Cooperation between Public and Private Construction Sectors. The ability of the construction industry to stimulate economic, social, and cultural growth could be derived from the strong linkage between the government and private sectors in the construction market [35]. In several emerging markets around the globe, different policy schemes have been devised to improve the capacity and involvement of private sector in construction projects. These policies and strategies allow both sectors to establish cooperation through incoming transformative technological advancements and methods to tackle complexities and challenges in infrastructure development [36].

In addition to utilizing technological processes to improve cooperation, various integrated project delivery models have been developed in the past decade [19]. Some of which include public-private partnership (PPP), integrated 
TABLE 11: Summary of hypothesis testing results for both public and private structural models.

\begin{tabular}{|c|c|c|c|c|c|c|}
\hline \multirow{3}{*}{ BIM adoption drivers } & \multicolumn{6}{|c|}{ Adoption models } \\
\hline & \multicolumn{3}{|c|}{ Public } & \multicolumn{3}{|c|}{ Private } \\
\hline & $\begin{array}{c}\text { Awareness } \\
\text { (AW) }\end{array}$ & $\begin{array}{c}\text { Intention } \\
\text { (INT) }\end{array}$ & $\begin{array}{c}\text { Decision } \\
\text { (DC) }\end{array}$ & $\begin{array}{c}\text { Awareness } \\
\text { (AW) }\end{array}$ & $\begin{array}{l}\text { Intention } \\
\text { (INT) }\end{array}$ & $\begin{array}{c}\text { Decision } \\
\text { (DC) }\end{array}$ \\
\hline Relative Advantage (RA) & $1.648^{*}$ & $1.275^{*}$ & $1.365^{*}$ & $0.521^{*}$ & $0.302^{*}$ & $0.631^{*}$ \\
\hline Compatibility (C) & -1.901 & -1.772 & -1.924 & -0.152 & -0.141 & -0.134 \\
\hline Complexity (CO) & -0.313 & -0.105 & -0.209 & -0.094 & 0.105 & -0.038 \\
\hline $\begin{array}{l}\text { Top Management Support } \\
\text { (TOS) }\end{array}$ & $0.778^{*}$ & 0.460 & 0.566 & -0.055 & $0.214^{*}$ & $0.272^{*}$ \\
\hline Organizational Readiness (OR) & -0.491 & -0.238 & -0.578 & 0.014 & 0.052 & -0.149 \\
\hline Financial Competency (FC) & $0.258^{*}$ & $0.594^{*}$ & $0.407^{*}$ & $0.354^{*}$ & $0.459^{*}$ & $0.794^{*}$ \\
\hline Communication Behavior (CB) & -1.707 & -1.698 & -1.605 & $0.509^{*}$ & 0.116 & 0.284 \\
\hline Social/Cultural Factors (SCF) & $0.814^{*}$ & $0.515^{*}$ & $0.711^{*}$ & -0.775 & -0.918 & -1.533 \\
\hline Government Pressure (GP) & $2.320^{*}$ & $2.128^{*}$ & $2.523^{*}$ & -0.720 & -960 & -1.477 \\
\hline Competitor Pressure (COP) & -1.521 & -1.403 & -1.295 & $0.521^{*}$ & $0.678^{*}$ & $0.976^{*}$ \\
\hline Customer Pressure (CP) & $0.533^{*}$ & $0.460^{*}$ & $0.453^{*}$ & 0.187 & $0.201^{*}$ & $0.316^{*}$ \\
\hline
\end{tabular}

NB estimates with ${ }^{*}$ have $p$ values less than 0.05 .

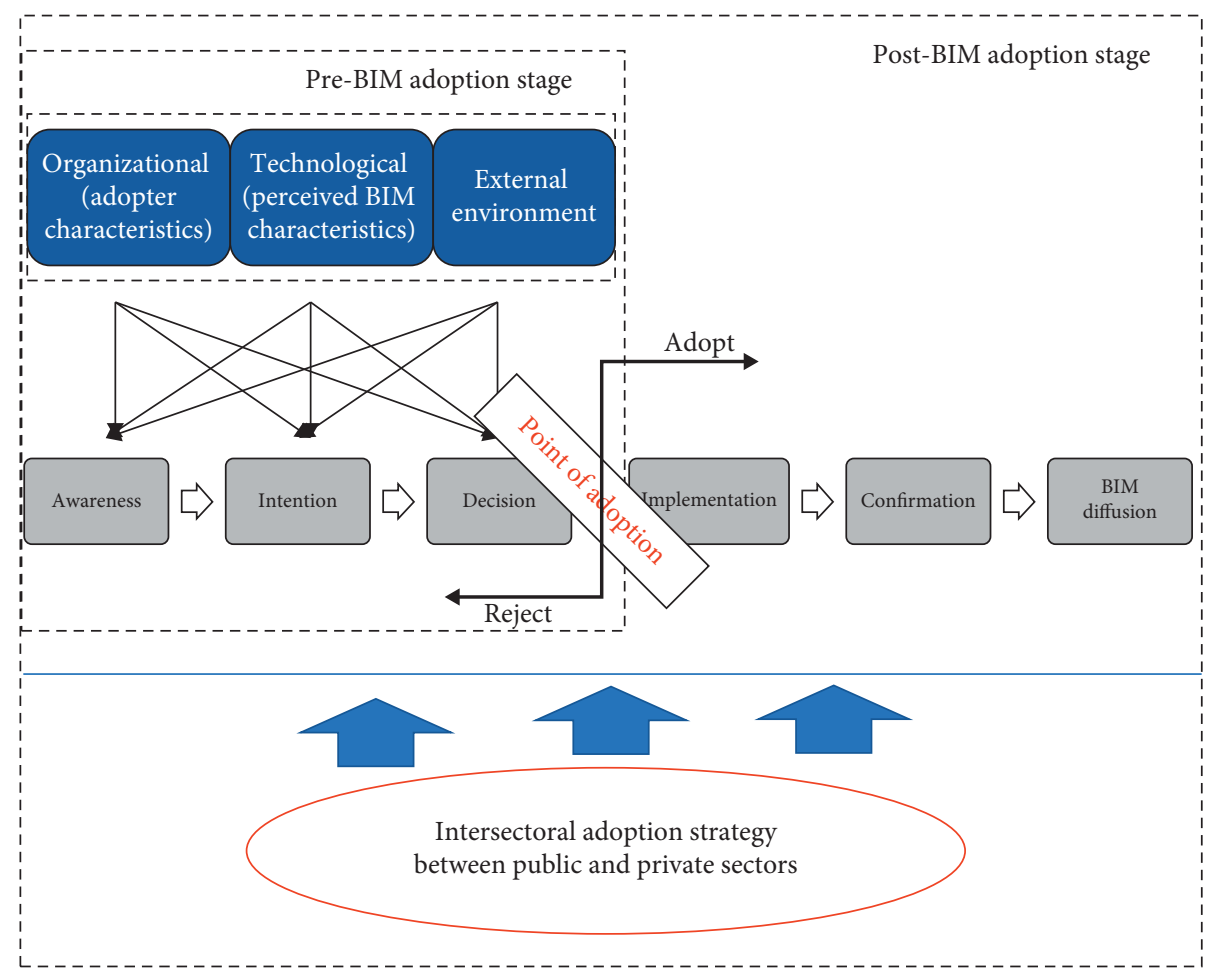

FIgURE 3: Conceptual IDT BIM adoption process (adopted from [10, 23]).

project delivery (IPD), and integrated design and delivery solutions (IDDSs), and project alliancing and delivering. With different features and characteristics, all of these project delivery models aim to create a motivating operational built environment for the architecture, engineering, and construction (AEC) industry [37]. Moreover, these models are able to enhance the integration of knowledge and information flow among different project players to improve the overall quality and operational efficiency in the construction business setting [32].
In this context, BIM has been proven to have a positive impact in enhancing integration among stakeholders through different stages of the project life cycle. For instance, amidst the housing challenges in many developing countries, several private housing and real estate developers are emerging to get their fair market share. This in turn creates a linkage between the government and private sectors and could be explained through the implementation of advanced process, construction method, or technology, such as BIM [38]. Hence, BIM adoption strategies and implementation 
schemes should be developed considering the relationship and cooperation of both private and public sectors along the project life cycle.

5.2. Public Construction Sector. In the public sector, experts agreed that Relative Advantage, Government Pressure, and Communication Behavior are the major drivers that affect BIM adoption in public construction projects. This coincides with the findings of $[2,21]$. The results highlighted that a comprehensive and capacity-based adoption strategies are needed to improve the competency of firms, as well as the project management performance of the public sector. During the Intention and Decision phases, Organizational Readiness and Communication Behavior are the key adoption components which allow the necessary preparations such as expert skill and resource capability within an organization $[10,22]$. Similarly, Financial Competency and Social/Cultural Factors are also significant factors that affect BIM adoption in the public sector. Ahuja et al. [22] reported that social and cultural attitudes influence technological adoption in the construction market.

Likewise, Government Pressure is the other BIM adoption enabler in public construction projects. When it comes to BIM adoption in infrastructure projects, business CEOs normally tend to rely on the government's initiative to support organizations and the holistic benefits it brings to the business environment [32]. This positive demand in turn usually tends to create a collaborative environment among stakeholders and the regulatory body [7]. In recent years, public-private partnership (PPP) schemes are becoming popular in the majority of Sub-Saharan African countries [39]. PPP is a framework between the public and private sectors with the aim of delivering public services whereby the private sector funds infrastructure projects [24]. Hence, as an alternative to tackle financial constraints, it is advisable for the Ethiopian government to encourage BIM adoption in PPP-enabled public infrastructure projects.

Nevertheless, the findings also highlighted the inhibitors that may negatively impact BIM adoption in public projects; including Compatibility, Complexity, and Communication Behavior. These inhibitors primarily center on the nature and organizational structure of firms. Thus, it is imperative to device strategies including capacity development programs that aim to improve the competency of local construction organizations. Moreover, government agencies, associations, universities, and other key stakeholders should take an initiative and provide BIM trainings, seminars, and international BIM adoption experiences to enhance BIM uptake in the public construction sector.

5.3. Private Construction Sector. The private construction sector is characterized by the financing and involvement of private clients in projects. The private construction sector is considered as the key element of country's development, especially in emerging markets such as Ethiopia. The SEM result indicates that during the Awareness stage, Organizational Readiness, Customer Pressure, Competitor Pressure, and Communication Behavior are the enablers of BIM adoption in private projects. Clearly, these findings are associated with organizational and environmental aspects of the TOE adoption model. This evidence benefits all key stakeholders including associations and universities to develop action plans and adoption schemes to improve the overall BIM uptake in the private sector.

Furthermore, drivers such as Top Management Support, Customer Pressure, Competitive Pressure, Communication Behavior, and Organizational Readiness affect the Intention and Decision stages of BIM adoption in private projects. The result coincides with the findings of $[1,2]$. Prior studies insisted that the private construction sector is usually tied with the proper coordination and leadership of top management in order to make crucial decisions regarding future business operations $[8,12]$. This is also greatly visible in the Ethiopian construction sector where the external political and economic factors greatly affect the construction business decisions [24]. Hence, the competency and readiness of local construction firms is key to compete against the big international competitors in the market.

In a broader sense, the majority of construction firms in Ethiopia associate innovation and technology adoption with regard to its overall technical and financials in the construction business environment. In this context, the findings provide empirical evidences to reinforce the current notion of BIM acceptance in both the public and private construction sectors. Understanding the potential enablers of BIM in project-specific concepts helps to address the key challenges that may hinder its adoption. More so, it is important to denote that stakeholder's readiness, and regulatory body's initiative to encourage and support local construction firms are crucial for the successful adoption of BIM in construction projects.

\section{Conclusion}

The purpose this study was to examine and compare BIM adoption models within the public and private construction sectors. The proposed models were presented in terms of Technology, Organization, Environment, Organizational Readiness, and Innovation Diffusion frameworks. The empirical findings reveal that Relative Advantage, Financial Competency, Government Pressure, Customer Pressure, and Social/Cultural Factors are the critical enablers that affect BIM adoption in public projects whereas Relative Advantage, Competitor Pressure, Financial Competency, Customer Pressure, and Communication Behavior affect BIM adoption in the private construction sector.

The contribution and novelty of this paper is threefold: (1) this study delivers a broader comparative empirical analysis to reinforce the current efforts of BIM adoption in the Ethiopian construction sector. This could be thought as a profound step to find a common ground among the public and private sectors. This in turn helps to strengthen the current business environment and improve the delivery of construction projects in the wider Sub-Saharan African region. (2) The paper also fills the gap of limited studies conducted worldwide in relation to intersectoral relationship among BIM implementation models in construction 
projects. (3) The other significant contribution lies in the practical aspect of projects by providing sufficient information regarding BIM adoption drivers for both sectors. This is helpful for construction firms, stakeholders, policy makers, and government officials to develop a national BIM policy for the Ethiopian construction industry.

In addition, unlike previous studies, this paper included the perspective of academia in the analysis of BIM adoption models. Academia is one of the key stakeholders which influences professional BIM capacity and understanding by introducing BIM in curriculums, and we should organize BIM trainings and facilitate conferences under the university-industry linkage framework. Future studies could focus on BIM adoption case studies along with project budget and organizational capacity. Similarly, comparative analysis within the type of projects including contract amount and delivery methods are a good area of exploration. It is imperative to grasp both theoretical, as well as practical perspective of experts to capture the unique features in the Ethiopian construction business environment.

\section{Data Availability}

The data underlying the results presented in the study are available within the manuscript.

\section{Conflicts of Interest}

The authors declare no conflicts of interest.

\section{References}

[1] G. Ngowtanasawan, "A causal model of BIM adoption in the Thai architectural and engineering design industry," Procedia Engineering, vol. 180, pp. 793-803, 2017.

[2] Y. Chen, Y. Yin, G. J. Browne, and D. Li, "Adoption of building information modeling in Chinese construction industry," Engineering, Construction and Architectural Management, vol. 26, no. 9, pp. 1878-1898, 2019.

[3] O. Olanrewaju, N. Chileshe, S. A. Babarinde, and M. Sandanayake, "Investigating the barriers to building information modeling (BIM) implementation within the Nigerian construction industry," Engineering, Construction and Architectural Management, vol. 27, no. 10, pp. 2931-2958, 2020.

[4] M. F. Arshad, M. J. Thaheem, A. R. Nasir, and M. S. A. Malik, "Contractual risks of building information modeling: toward a standardized legal framework for design-bid-build projects," Journal of Construction Engineering and Management, vol. 145, no. 4, pp. 1-13, 2019.

[5] L. Liao and E. Ai Lin Teo, "Organizational change perspective on people management in BIM implementation in building projects," Journal of Management in Engineering, vol. 34, no. 3, Article ID 04018008, 2018.

[6] M. F. Antwi-Afari, H. Li, E. A. Pärn, and D. J. Edwards, "Critical success factors for implementing building information modelling (BIM): a longitudinal review," Automation in Construction, vol. 91, pp. 100-110, 2018.

[7] C. M. Herr and T. Fischer, "BIM adoption across the Chinese AEC industries: an extended BIM adoption model," Journal of Computational Design and Engineering, vol. 6, no. 2, pp. 173-178, 2019.
[8] O. Aljobaly and A. Banawi, "Evaluation of the Saudi construction industry for adoption of building information modelling," Advances in Intelligent Systems and Computing, Springer International Publishing, Berlin, Germany, pp. 488-498, 2020.

[9] S. Lee, J. Yu, and D. Jeong, "BIM acceptance model in construction organizations," Journal of Management in Engineering, vol. 31, no. 3, pp. 1-13, 2015.

[10] A. L. Ahmed and M. Kassem, "A unified BIM adoption taxonomy: conceptual development, empirical validation and application," Automation in Construction, vol. 96, pp. 103127, 2018.

[11] A. T. Haron, Organizational Readiness to Implement Building Information Modeling: A Framework for Design Consultants in Malaysia, University of Salford Manchester, Salford, UK, 2013.

[12] B. Ozorhon and U. Karahan, "Critical success factors of building information modeling implementation," Journal of Management in Engineering, vol. 33, no. 3, 2017.

[13] Y. Hong, S. M. E. Sepasgozar, A. F. F. Ahmadian, and A. Akbarnezhad, "Factors influencing BIM adoption in small and medium sized construction organizations," in Proceedings of the 33rd International Symposium on Automation and Robotics in Construction (ISARC), pp. 452-461, Auburn, AL, USA, July 2016.

[14] L. Liao and E. A. L. Teo, "Critical success factors for enhancing the building information modelling implementation in building projects in Singapore," Journal of Civil Engineering and Management, vol. 23, no. 8, pp. 1029-1044, 2017.

[15] P. Teo, S. Zheng, H. Si, and K. Xu, "Critical challenges for BIM adoption in small and medium-sized enterprises: evidence from China," Advances in Civil Engineering, vol. 2019, Article ID 9482350, 14 pages, 2019.

[16] D. W. M. Chan, T. O. Olawumi, and A. M. L. Ho, "Perceived benefits of and barriers to building information modelling (BIM) implementation in construction: the case of Hong Kong," Journal of Building Engineering, vol. 25, Article ID 100764, 2019.

[17] M. Ghazaryan, "Pecularities of BIM adoption in Armenia," E3S Web of Conferences, vol. 97, Article ID 01025, 2019.

[18] X. Ma, A. P. C. Chan, Y. Li et al., "Critical strategies for enhancing BIM implementation in AEC projects: perspectives from Chinese practitioners," Journal of Construction Engineering and Management, vol. 146, no. 2, pp. 1-10, 2020.

[19] P. Piroozfar, E. R. P. Farr, A. H. M. Zadeh, S. Timoteo Inacio, S. Kilgallon, and R. Jin, "Facilitating building information modelling (BIM) using integrated project delivery (IPD): a UK perspective," Journal of Building Engineering, vol. 26, Article ID 100907, 2019.

[20] S. O. Babatunde, D. Ekundayo, A. O. Adekunle, and W. Bello, "Comparative analysis of drivers to BIM adoption among AEC firms in developing countries," Journal of Engineering, Design and Technology, vol. 18, no. 6, pp. 1425-1447, 2020.

[21] S. H. A. Ahmed and S. M. A. Suliman, "A structure equation model of indicators driving BIM adoption in the Bahraini construction industry," Construction Innovation, vol. 20, no. 1, pp. 61-78, 2020.

[22] R. Ahuja, A. Sawhney, M. Jain, M. Arif, and S. Rakshit, "Factors influencing BIM adoption in emerging markets-the case of India," International Journal of Construction Management, vol. 20, no. 1, pp. 65-76, 2020.

[23] E. M. Rogers, Diffusion of Innovations, The Free Press, London, UK, 3rd edition, 2003. 
[24] G. Y. Debela, "Critical success factors (CSFs) of public-private partnership (PPP) road projects in Ethiopia," International Journal of Construction Management, pp. 1-12, 2019.

[25] H. N. Mosse, M. Njuguna, and C. Kabubo, "Influence of building information modelling (BIM) on engineering contract management in Nairobi, Kenya," World Journal of Engineering and Technology, vol. 8, no. 3, pp. 329-346, 2020.

[26] T. E. Kwofie, C. Aigbavboa, A. Baiden-Amissah et al., "Ontology of the communication performance prospects of building information modelling adoption among project teams in construction project delivery," Journal of Construction in Developing Countries, vol. 25, no. 1, pp. 21-43, 2020.

[27] T. Almuntaser, M. O. Sanni-Anibire, and M. A. Hassanain, "Adoption and implementation of BIM-case study of a Saudi Arabian AEC firm," International Journal of Managing Projects in Business, vol. 11, no. 3, pp. 608-624, 2018.

[28] W. I. Enegbuma, G. U. Aliagha, K. N. Ali, and Y. Y. Badiru, "Confirmatory strategic information technology implementation for building information modelling adoption model," Journal of Construction in Developing Countries, vol. 21, no. 2, pp. 113-129, 2016.

[29] J. Rogers, H.-Y. Chong, and C. Preece, "Adoption of Building Information Modelling technology (BIM) Perspectives from Malaysian engineering consulting services firms," Engineering, Construction and Architectural Management, vol. 23, no. 2, pp. 237-260, 2015.

[30] R. Masood, M. K. N. Kharal, and A. R. Nasir, "Is BIM adoption advantageous for construction industry of Pakistan?" in Proceedings of the Fourth International Symposium on Infrastructure Engineering in Developing Countries, pp. 229-238, Elsevier B.V., Karachi, Pakistan, December 2014.

[31] N. A. Adillah Ismail, M. Maisham, Z. A. Mohd Zaki, R. R. R. Muhammad Rooshdi, and S. R. Sahamir, "The mediating effects of cost estimates reliability on BIM adoption: SEM model analysis," IOP Conference Series: Earth and Environmental Science, vol. 385, no. 1, Article ID 012070, 2019.

[32] C. Y. Chang, W. Pan, and R. Howard, "Impact of building information modeling implementation on the acceptance of integrated delivery systems: structural equation modeling analysis," Journal of Construction Engineering and Management, vol. 143, no. 8, pp. 1-10, 2017.

[33] Y. Hong, A. Hammad, X. Zhong et al., "Comparative modeling approach to capture the differences in BIM adoption decision-making process in Australia and China," Journal of Construction Engineering and Management, vol. 146, no. 2, pp. 1-15, 2020.

[34] S. Banihashemi, M. R. Hosseini, H. Golizadeh, and S. Sankaran, "Critical success factors (CSFs) for integration of sustainability into construction project management practices in developing countries," International Journal of Project Management, vol. 35, no. 6, pp. 1103-1119, 2017.

[35] S. Belay, J. Goedert, A. Woldesenbet, and S. Rokooei, "A hybrid delphi-AHP based analysis of construction projectspecific success factors in emerging markets: the case of Ethiopia," Cogent Engineering, vol. 8, no. 1, Article ID 1891701, 2021.

[36] R. Eadie, M. Browne, H. Odeyinka, C. McKeown, and S. McNiff, "BIM implementation throughout the UK construction project lifecycle: an analysis," Automation in Construction, vol. 36, pp. 145-151, 2013.

[37] M. N. M. Nawi, A. T. Haron, Z. A. Hamid et al., "Improving integrated practice through building information modelingintegrated project delivery (BIM-IPD) for Malaysian industrialised building system (IBS) construction projects," Malaysian Construction Research Journal, vol. 15, no. 2, pp. 29-38, 2014.

[38] R. Al-Saadi and A. Abdou, "Factors critical for the success of public-private partnerships in UAE infrastructure projects: experts' perception," International Journal of Construction Management, vol. 16, no. 3, pp. 234-248, 2016.

[39] N. Chileshe, C. W. Njauau, B. K. Kibichii, L. N. Macharia, and N. Kavishe, "Critical success factors for public-private partnership (PPP) infrastructure and housing projects in Kenya," International Journal of Construction Management, vol. 20, no. 6, pp. 1-12, 2020. 